\title{
Volcanic seismicity at Montserrat, a comparison between the 2005 dome growth episode and earlier dome growth.
}

\author{
R. Luckett ${ }^{\mathrm{a}}$, S. Loughlin ${ }^{\mathrm{a}}$, S. De Angelis ${ }^{\mathrm{b}}$, G. Ryan ${ }^{\mathrm{c}}$ \\ ${ }^{\text {a }}$ British Geological Survey, Murchison House, Edinburgh, UK. \\ ${ }^{\mathrm{b}}$ Montserrat Volcano Observatory, Montserrat, West Indies. \\ ${ }^{c}$ Aukland University, New Zealand.
}

\begin{abstract}
In 2005 Soufrière Hills Volcano on Montserrat started its third major episode of dome growth since the current eruption started in 1995. The style of seismicity associated with dome growth has changed, in particular the events known as 'hybrid' earthquakes have reduced in numbers by an order of magnitude compared to previous dome growth episodes. In the past, hybrid earthquakes have been associated with magma ascent and so it is surprising to observe prolonged periods of rapid dome growth during which very few hybrid earthquakes are recorded. In addition, the frequency of the codas of hybrid earthquakes, as well as of some of the so called 'long-period' events, has changed. The changes in recorded seismicity have had a marked effect on the techniques used to monitor the state of the volcano and those events that continue to be recorded in large numbers ('rockfall events') have been used to assess the state of activity at the volcano.
\end{abstract}




\section{Introduction}

Soufrière Hills on Montserrat in the West Indies is an andesitic dome building volcano. The current eruption started in 1995 (Young et al., 1998) and since then intermittent dome growth has taken place in the crater at the top of the edifice. The first two episodes of such growth were between September 1995 and March 1998 and between November 1999 and July 2003. The third episode started in August 2005. As would be expected, there is a marked difference in the seismicity recorded during episodes of dome growth compared to that recorded during the repose periods between them. There is also a difference in the seismicity typical of each episode of growth. While there are many publications concerning the seismicity associated with the first extrusive episode at Montserrat (e.g. Miller et al., 1998, Aspinall et al., 1998, Neuberg et al., 1998), the more recent episodes are less well documented.

As part of its monitoring program the Montserrat Volcano Observatory (MVO) has maintained an array of digitally telemetered broadband seismometers on Montserrat since 1996. This network was upgraded at the start of 2005 (Luckett et al., 2007) and now consists of 8 Guralp CMG-40T 3 component 30 second seismometers and 2 Mark Products L4 vertical $1 \mathrm{~Hz}$ instruments (Figure 1). All stations are digitised and GPS time-stamped at the site using Guralp DM24 digitisers and telemetered to the observatory using spread-spectrum VHF radio-modems. $100 \mathrm{~Hz}, 24$ bit seismic data are recorded continuously and a triggering algorithm detects events in real time. Events are classified into a small number of types and the counts of these types are used as a monitoring tool. The event types recognised on Montserrat are volcano-tectonic earthquakes, long-period earthquakes, hybrid earthquakes, rockfall signals and long-period rockfall signals (Miller et al., 1998).

In the years between 1992 and the start of the eruption at Soufrière Hills in 1995 there were several thousand volcano-tectonic earthquakes (Aspinall et al., 1998, Power et al., 1998). Similar seismicity has been observed associated with dome emplacement at many other volcanoes (Zobin, 2003) and has been linked to magma forcing a route to the surface and the associated stresses (Roman et al., 2006). Once dome growth had begun hybrids - events with a similar initial phase to the volcano-tectonic events but with an additional lower frequency monochromatic phase - replaced volcano-tectonic earthquakes as the most common event type. Very large numbers of this type of event continued throughout the first dome growth episode, and to a lesser degree throughout the second episode. In the repose periods there was very little seismicity, although in the first repose period there were regular steam explosions. This report describes the seismicity recorded during the third episode of dome growth and compares it with that recorded during the first. Some speculation is included about the reasons for changes in this seismicity but no modelling is done or hypotheses tested. Rather, observations are presented in the hope that they will be useful to people monitoring other volcanoes. These observations also place some important constraints on the sources of volcanic seismicity associated with dome growth that need to be considered in future models. An example is given of how seismic monitoring has been adjusted to allow for changes in volcanic seismicity.

\section{Chronology of 2005 dome}

Between the collapse of the previous dome in July 2003 and June 2005 there was little seismicity associated with the volcano. Averaged over the whole period there were roughly 100 events per month compared with an average of over 2500 events per month for the 3.5 year duration of the preceding dome growth episode. The first significant and sustained increase in seismicity began on April $15^{\text {th }} 2005$ when a vigorous vent opened on the crater rim, heard throughout the island as a 'jet engine' noise. There were a small number of volcano-tectonic events associated with the 
venting and from this point seismicity increased, with 9 episodes of volcano-tectonic earthquakes in the next 2 months, each lasting between a few hours and a few days and consisting of one or two events each hour.

On June $13^{\text {th }}, 2005$ a thunderstorm over the volcano cleared to reveal vigorous steam and ash venting from several places within the crater, perhaps signifying deeper penetration by meteoric water than usual. This venting was accompanied by an episode of volcano-tectonic events similar in duration and density to those in previous weeks, but this time long-period and hybrid earthquakes were also recorded. For the next two weeks there was elevated venting activity but little seismicity apart from low amplitude tremor with energy in the frequency band between $1 \mathrm{~Hz}$ and $5 \mathrm{~Hz}$ and no particular spectral peaks. When the summit could be observed this tremor was seen to coincide with particularly energetic venting. On June $28^{\text {th }}$ there was the first of 5 explosions; each of these had an ash cloud higher than $3 \mathrm{~km}$ but no juvenile magma was erupted. The explosions had a clear seismic signature with a high amplitude, nearly monochromatic phase at the start. Each explosion had a slightly different frequency for this phase but all had a frequency of less than $1 \mathrm{~Hz}$. Each explosion was associated with a small number of volcanotectonic and hybrid earthquakes that occurred both before and after the explosion itself. These explosions were similar in many ways to those in 1997 (Druitt et al., 2002).

The new lava dome was first seen on August $8^{\text {th }}$ and from then on its growth was measured using photogrammetric methods (Sparks et al., 1998) and ground-based LiDAR (Light Detection And Ranging: Jones, 2006). The accuracy of the growth rates given here is estimated to be $15 \%$ or better. For the first 2 months of dome growth there was very little seismicity, with an average of 5 events per day triggering the network (compared with a background level of 2 events per day in March). The growth rate for the new dome was estimated to be $0.5 \mathrm{~m}^{3} \mathrm{~s}^{-1}$. The pattern changed in October when about 650 small hybrid earthquakes were recorded over an interval of 3 weeks. The number of rockfall signals increased markedly and a slight increase in long-period seismicity was also observed. For the next 3 months there was an average of 15 events each day, an average of 12 of which were rockfalls. Over this period the growth rate was, on average, $2.4 \mathrm{~m}^{3} \mathrm{~s}^{-1}$. On February $9^{\text {th }}, 2006$ another venting episode signalled an acceleration in extrusion rate to over 10 $\mathrm{m}^{3} \mathrm{~s}^{-1}$. The number and energy of rockfall signals again increased with an average of 80 each day for the next 3 months. The number of long-period earthquakes recorded also increased to more than 10 a day.

On May $20^{\text {th }}$ there was a major dome collapse that removed the whole dome and some remnants from previous domes (approximately 112 million $\mathrm{m}^{3}$ (DRE) of material, Loughlin et al., 2008). The only seismic precursor for this collapse was a single high amplitude long-period event about 3 hours beforehand. The collapse led to explosions and an $\mathrm{SO}_{2}$ cloud that reached a height of 20 $\mathrm{km}$ and had a mass of 200 kilotons (Carn et al., 2007). This is far more gas than in a previous, larger collapse on 12-13 July 2003 (Herd et al., 2005). A new lava dome started to grow within hours of the collapse. By $27^{\text {th }}$ June the new dome had a volume of about 26 million $\mathrm{m}^{3}$ and was growing at an average rate of $8 \mathrm{~m}^{3} \mathrm{~s}^{-1}$ (Loughlin et al., 2008).

\section{Seismicity associated with 2005 dome}

Figure 2 shows daily counts for the different event types for the 8 months preceding the May $20^{\text {th }}$ 2006 collapse. For comparison, 8 months of 1996/1997 are also shown when the dome was growing at a similar rate (Sparks et al., 1998). The main difference between the two intervals is the almost complete lack of hybrid earthquakes in 2005/2006. The various event types are discussed here in turn. 


\section{Volcano-tectonics}

Very few volcano-tectonic earthquakes were recorded during the growth of the 2005 dome, being mainly restricted to two episodes in the last week of September 2005 and on February $7^{\text {th }} 2006$. These events were located using the same method as the hybrids, as described below, and were found to have similar locations.

\section{Hybrids}

There has been a very marked decrease in the number of hybrid earthquakes on Montserrat. Throughout 1997 an average of 1600 events were classified as hybrids each month. These hybrids often occurred in swarms that were correlated with tilt data indicating short term increases in pressurisation within the conduit (Voight et al., 1999). Pyroclastic flows often followed such swarms and so seismicity could be used in short term forecasting. As might be expected, this type of event almost disappeared in the two repose periods and started again when dome growth resumed each time. However, they failed to reoccur in similar numbers during either of the more recent dome growth episodes. In particular, there were fewer than 150 hybrids a month recorded on average between the start of the 2005 episode and the May $20^{\text {th }}$ collapse. The lack of hybrids had a considerable effect on monitoring, with very high estimated magma ascent rates (for example over $10 \mathrm{~m}^{3} \mathrm{~s}^{-1}$ in February 2006) having virtually no accompanying seismicity that could be attributed directly to the movement of this magma. The May $20^{\text {th }} 2006$ collapse, the second largest known at this volcano, effectively had no seismic precursors to give warning of such a major event.

The dominant frequency of hybrids in 2005/2006 was different to that earlier in the eruption (Figure 3). Although the frequency of the long-period part of hybrids in 1997 varied, it was predominantly between $1 \mathrm{~Hz}$ and $2 \mathrm{~Hz}$, the same frequency as the few long-period earthquakes that were recorded at that time. The hybrids recorded during the growth of the 2005 dome have typically had codas with energy in the region of $3 \mathrm{~Hz}$ or $4 \mathrm{~Hz}$. Figure 4 shows a comparison between a typical 1997 hybrid and an example from 2005. The higher dominant frequency was also observed in many events identified as long-period events in 2005/2006 but, as discussed below, other longperiod events continued to be recorded with frequencies between $1 \mathrm{~Hz}$ and $2 \mathrm{~Hz}$.

Most of the hybrids recorded in 2005 and before May $20^{\text {th }}$ in 2006 were too small to reliably pick arrival times, so relatively few were located. Of those routinely located the 120 events with the best signal-to-noise ratio were reanalysed. Cross-correlation shows that waveforms at a given station are extremely similar from event to event, indicating a single source area. Accordingly, a Joint Hypocentre Determination (JHD) method similar to that used for previous Montserrat data by Rowe et al. (2004) and Ottemoller (2008) was used to relocate the events. The resulting locations (Figure 5) cluster beneath the dome at a depth of approximately $2 \mathrm{~km}$ below sea-level. This source region is the same as that found for hybrids throughout the eruption. Changes in the waveforms of hybrid events are thus not due to differences in path from different source regions.

Hybrid and long-period earthquakes have generally been treated together in terms of source modelling and much work has been done in this field, starting with Aki et al. (1977). Many models have concentrated on interface waves in the boundary between a fluid and country rock (e.g. Chouet, 1988, Neuberg et al., 2000) and resonance in a gas-filled dike was put forward by Schlindwein et al (1995). The trigger needed to initiate such sources has been described as an ash injection into cracks (Molina et al., 2004) or the brittle failure of magma as it passes through the glass transition (Neuberg et al., 2006). These models can accommodate the slight changes in frequency observed at Montserrat through reasonable changes in initial conditions but it is more difficult to explain the almost complete lack of such seismicity when magma extrusion rates are 
165

166

167

168

169

170

171

172

173

174

175

176

177

178

179

180

181

182

183

184

185

186

187

188

189

190

191

192

193

194

195

196

197

198

199

200

201

202

203

204 known to be high. Petrological studies show that the magma being erupted has changed very little over the last 10 years (J. Divine pers. Comm.) but something must have changed in the volcanic system to explain the differences in seismicity being recorded. One explanation is that the country rock surrounding the conduit is fractured to such a degree that changes in stress due to rising magma can be accommodated without further failure. However, for this to explain the lack of hybrids the trigger for hybrids would have to be a brittle fracture in the vicinity of the conduit. This model has problems explaining the repeatability that is an observed property of hybrid earthquakes (Neuberg, 2000). Another explanation is that a change in the geometry of the conduit is in some way responsible for the relative lack of seismicity. This could also explain the change in frequency of the hybrid codas, although the modelling to show this is beyond the scope of this paper.

\section{Rockfalls and Long-periods}

Throughout the eruption there has been a strong link between some long-period events and rockfalls, with the two types of event often occurring consecutively to form events known as longperiod rockfalls (Figure 6 ). Rockfall signals have often had $1 \mathrm{~Hz}$ to $2 \mathrm{~Hz}$ peaks in their spectra and discrete long-period events occur during or just after rockfall signals, as well as before the rockfall as is most often the case. In 1997 long-period rockfall events were investigated using a pressure sensor (Luckett et al., 2002). It was shown that the long-period part of long-period rockfalls correlates with an acoustic wave, indicating that the signal is linked to gas escaping violently from the dome. Although no pressure sensor was deployed in 2006, it was noted that jets of gas and ash were expelled from the dome preceding some rockfalls. The seismic events associated with such rockfalls are similar to long-period rockfalls in 1997, with the long-period part being of similar frequency.

One of the most interesting things about the long-period earthquakes in 2005 is that while some have the same frequency as hybrids, i.e. between $3 \mathrm{~Hz}$ and $5 \mathrm{~Hz}$, others have the same dominant frequency as previously, i.e. between $1 \mathrm{~Hz}$ and $2 \mathrm{~Hz}$. An example of each is shown in Figure 7 . The long-period events with higher frequencies, similar to the frequency of the codas of recent hybrids, could have the same source as hybrid events but have lost their high frequency initial phase due to attenuation, as suggested in Neuberg et al. (1998). However those with lower frequencies must have a different source.

While not all long-period events with frequency in the $1 \mathrm{~Hz}$ to $2 \mathrm{~Hz}$ band occur within a short time of a rockfall signal, most do. These signals have a source that is, at least sometimes, related to gas escaping from the surface of the dome. It seems likely that long-period events with similar frequencies have a similar source. Thus all $1 \mathrm{~Hz}$ to $2 \mathrm{~Hz}$ long-period earthquakes, as well as longperiod rockfalls, are probably related to degassing. That a considerable volume of gas was trapped within the 2005 dome was shown on May $20^{\text {th }} 2006$ when satellite images after the collapse showed that 200 kilotons of $\mathrm{SO}_{2}$ had been released (Carn et al., 2007). This is much more gas than was measured after a larger collapse in July 2003 (Herd et al., 2005). There was no evidence for deep excavation of the conduit during the May $20^{\text {th }}$ collapse so the gas must have largely been contained within the dome, as postulated for previous collapses (Edmonds et al., 2003). Considering that the gas in the dome will act as a buffer between the top of the conduit and the surface it seems unlikely that gas escaping from the conduit can explain the long-period events associated with rockfalls. Rather, these long-period events are related to gas movement within the dome itself. The events were not located because their emergent nature makes it impossible to pick arrival times. However low-frequency events on Unzen were located within the dome (Nakada et al., 1999), supporting such a hypothesis on Montserrat. As discussed above, long-period events have long been associated with the movement of gas within cracks or other structures. Long-period events associated with rockfalls could be caused by resonance in cracks 
or voids within the dome. The regular occurrence of long-periods both before and after the start of a rockfall signal can be speculatively explained by considering that, while the emergence of a violent jet of gas at the surface can start a landslide, it is also true that such a landslide can cause a localised depressurisation and therefore a movement of gas near the surface. If there was more gas in the 2005 dome than was the case in 1997 then that would explain the increased number of long-period and long-period rockfall events.

\section{Monitoring}

Rockfalls and long-period rockfalls appear to be a direct result of lava dome growth, rather than of the movement of magma in the conduit. However, their analysis is the best seismic monitoring tool available when the dome is growing and there is little other seismicity. The best method found so far is to plot cumulative rockfall energy in a similar approach to that used on Mount St Helens in 1981 and 1982 (Malone et al., 1983). Seismic energy at any one station is calculated for each rockfall and when these values are added together over time the resulting 'cumulative rockfall energy' is useful for detecting changes in dome growth, whether in extrusion rate, direction or style of growth. The sharp changes in the slope of the line in Figure 8 (which are repeated on similar plots for other stations) correlate with changes in dome growth rate and direction as indicated by the labels. This has important connotations for monitoring volcanic hazard as it gives the MVO warning of potentially important changes when the dome is hidden from sight by cloud (which can be the case for many consecutive days). Most major dome collapses have occurred during or immediately after a change in the direction of growth or extrusion rate (Loughlin et al 2008). Higher extrusion rates may make a collapse or explosive event more likely (Calder et al., 2002) but the highest extrusion rates are not always accompanied by the highest rockfall energy. Monitoring rockfall activity can nevertheless give the first indication of a possible change in direction of dome growth or change in extrusion rate, both of which could lead to increased risk of dome collapse.

\section{Conclusions}

Seismicity associated with dome growth at Montserrat has decreased over the duration of the 12 year eruption. The reasons for these changes are not understood, but they are reported here as they have important implications for both the modelling of volcanic long-period seismic sources and for volcanic monitoring. In particular the lack of hybrid earthquakes to interpret in terms of increased volcanic hazard, has forced changes in procedure at the MVO. Methods have been developed for using the signals caused by rockfalls on the dome to indicate changes in extrusion rate and/or direction of growth. Thus seismic monitoring remains important to the observatory despite the relative lack of deeper seismicity.

One explanation for the lack of hybrids is that the rock surrounding the conduit has become so fractured after 10 years of seismic activity that the stresses required for new fractures do not occur, despite considerable forces acting due to rapidly ascending magma. If this were to explain the lack of hybrids then the trigger for such events would have to be a fracture near to the conduit, a model that may fail to explain the repeatability of such events. It has also been suggested that the rock immediately surrounding the conduit has become more plastic due to heating. A consideration of the properties of andesite shows that this is not the case. Assuming a magma temperature of $860^{\circ} \mathrm{C}$ and thermal diffusivity of $7 \times 10^{7} \mathrm{~m}^{2} \mathrm{~s}^{-1}$ (Sparks et al., 2000) rock $100 \mathrm{~m}$ from the conduit will have increased in temperature by less than $30^{\circ} \mathrm{C}$ after 20 years. Perhaps the most likely explanation is that the conditions for a trigger within the conduit itself have changed due to changes in conduit geometry. It is possible that conduit changes could also explain the change in coda frequency of those hybrids that are still recorded (Jousset et al., 2003), but the modelling necessary to show this is beyond the scope of this paper. When considering changes to the 
source of hybrids it must be taken into account that their source has remained in the same place, within measurement uncertainty, throughout the eruption. The locus of extrusion has also effectively remained the same, making any major change in the path taken by magma to the surface unlikely. Any model of the source of long-period seismicity associated with dome growth must allow for aseismic magma ascent to occur at similar rates to that occurring when seismicity is recorded.

261

262

263

264

265

266

267

268

269

270

271

272

273

274

275

276

277

278

279

280

281

282

283

284

285

286

287

There are two types of long-period event being recorded on Montserrat. One type has similar dominant frequencies to the codas of recent hybrids, with spectral peaks near $3 \mathrm{~Hz}$ or $4 \mathrm{~Hz}$. The other type continues to have frequencies between $1 \mathrm{~Hz}$ and $2 \mathrm{~Hz}$, as was true of both hybrid codas and long-periods earlier in the eruption. The first type of long-period earthquake can be considered to be hybrids for which the initial phase is not recorded, as was previously thought. However the second type must have a different source. Because this second type of long-periods have similar frequencies to previous hybrids, they were probably always present but indistinguishable from the first type, which still have similar frequencies to hybrids now that these frequencies have changed.

The coincidence of gas jetting at the surface of the dome and long-period earthquakes with frequencies in the $1 \mathrm{~Hz}$ to $2 \mathrm{~Hz}$ range, combined with the knowledge that there is a huge quantity of gas stored within the dome, makes it unlikely that these events are connected to processes within the conduit, as is held to be true for hybrid earthquakes. Instead these events seem to be linked to resonances within the dome itself. This explains their close relationship with rockfall signals, either a jet of gas can dislodge loose blocks on the surface of the dome or gravity driven rockfalls can cause a sudden depressurisation near to the surface and a subsequent escape of gas.

\section{Acknowledgements}

The authors would like to thank the staff of the Montserrat Volcano Observatory.

This article is published with the permission of the Executive Director of the British Geological Survey (NERC).

The authors would like to thank two anonymous reviewers for their helpful comments. 


\section{References}

Aki, K., Fehler, M., Das, S., 1977. Source mechanism of volcanic tremor: Fluid-driven crack models and their application to the 1963 Kilauea eruption. J. Volcanol. Geotherm. Res. 2:259-287.

Aspinall, W.P., Miller, A.D., Lynch, L.L, Latchman, J.L., Stewart, R.C., White, R.A., Power, J.A., 1998. Soufrière Hills eruption, Montserrat, 1995-1997: volcanic earthquake locations and fault plane solutions. Geophys. Res. Lett. 25:3397-3400.

Calder, E., Luckett, R., Sparks, R.S.J., Voight, B., 2002. Mechanisms of lava dome instability and generation of rockfalls and pyroclastic flows at Soufrière Hills Volcano, Montserrat. In: Druitt, T.H., Kokelaar, B.P. (Editors), The eruption of Soufrière Hills Volcano, Montserrat, from 1995 to 1999. Geological Society, London, Memoir 21, pp. 173-191.

Carn S.A., Krotkov, N.A., Yang, K., Hoff, R.M., Prata, A.J., Krueger, A.J., Loughlin, S.C., Levelt, P.F., 2007. Extended observations of volcanic $\mathrm{SO}_{2}$ and sulfate aerosol in the stratosphere. Atmos. Chem. Phys. Discuss. 7:2857-2871.

Chouet, B.A., 1988. Resonance of a Fluid-driven crack: radiation properties and implications for the source of long-period events and harmonic tremor. J. Geophys. Res. 93:4373-4400.

Druitt T.H., Young S.R., Baptie B., Bonadronna C., Calder E.S., Clarke A.B., Cole P.D., Harford C.L., Herd R.A., Luckett R., Ryan G., Voight B., 2002. Episodes of cyclic Vulcanian explosive activity with fountain collapse at Soufriere Hills volcano, Montserrat. In: Druitt T.H., Kokellar B.P. (Editors), The eruption of Soufriere Hills volcano, Montserrat, from 1995 to 1999, Geological Society, London, Memoir 21, pp. 281-306.

Edmonds, M., Oppenheimer, C., Pyle, D.M., Herd, R.A., Thompson, G., 2003. SO2 emissions from Soufriere Hills Volcano and their relationship to conduit permeability, hydrothermal interaction and degassing regime. J. Volcanol. Geotherm. Res. 124:23-43.

Herd, R.A., Edmonds, M., Bass, V., 2005. Catastrophic lava dome failure at Soufriere Hills Volcano, Montserrat, 12-13 July 2003. J. Volcanol. Geotherm. Res. 148:234- 252.

Jones, L.D., 2006. Monitoring landslides in hazardous terrain using terrestrial LiDAR: an example from Montserrat. Quarterly Journal of Engineering Geology and Hydrogeology, 39: 371-373.

Jousset, P., Neuberg, J. and Sturton, S., 2003. Modelling the time-dependent frequency content of low-frequency volcanic earthquakes. J. Volcanol. Geotherm. Res., 128: 201-223.

Loughlin, S., Luckett, R., Christopher, T., Druitt, T., Jones, L., Baptie, B., Ryan, G., Strutt, M., 2008. Unprecedented gas release from a large volume and rapid dome collapse at SHV 20 May 2006. Submitted to J. Volcanol. Geotherm. Res.

Luckett, R., Baptie, B., Neuberg J., 2002. The relationship between degassing and rockfall signals at Soufrière Hills volcano, Montserrat. In: Druitt T.H., Kokellar B.P. (Editors), The eruption of Soufriere Hills volcano, Montserrat, from 1995 to 1999, Geological Society, London, Memoir 21, pp. 595-602. 
Luckett, R., Baptie, B., Ottemoller, L., Thompson, G., 2007. Seismic Monitoring of the Soufrière Hills Volcano, Montserrat. Seismol. Res. Lett. 78:192-201.

Malone, S.D., Boyko, C. and Weaver, C.S., 1983. Seismic Precursors to the Mount St. Helens Eruptions in 1981 and 1982. Science, 221: 1376-1378.

Miller, A.D., Stewart, R.C., White, R.A., Luckett, R., Baptie, B., Aspinall, W., Latchman, J.L., Lynch, L.L., Voight, B., 1998. Seismicity associated with dome growth and collapse at the Soufrière Hills Volcano, Montserrat. Geophys. Res. Lett. 25:3401-3404.

Molina, I., Kumagai, H., Yepes, H., 2004. Resonances of a volcanic conduit triggered by repetitive injections of an ash-laden gas. Geophys. Res. Lett. 31:L03603 doi:10.1029/2003GL018934

Nakada, S., Shimizu, H. and Ohta, K., 1999. Overview of the 1990-1995 eruption at Unzen volcano. J. Volcanol. Geotherm. Res. 89:1-22.

Neuberg, J., Baptie B., Luckett, R., Stewart, R., 1998. Results from the broadband seismic network on Montserrat. Geophys. Res. Lett. 25:3661-3664.

Neuberg, J., 2000, Characteristics and causes of shallow seismicity in andesite volcanoes. Royal Society of London. Philosophical Transactions. Series A. Mathematical, Physical and Engineering Sciences, 358, pp. 1533-1546.

Neuberg, J., Luckett R., Baptie, B., Olsen, K., 2000. Models of tremor and low-frequency earthquake swarms on Montserrat. J. Volcanol. Geotherm. Res. 101:83-104.

Neuberg, J., Tuffen, H., Collier, L., Green, D., Powell, T., Dingwell, D., 2006. The trigger mechanism of low-frequency earthquakes on Montserrat. J. Volcanol. Geotherm. Res. 153:37-50.

Ottemoller, L., 2008. Seismic hybrid swarm precursory to a major lava dome collapse: 9-12 July 2003, Soufriere Hills Volcano, Montserrat. J. Volcanol. Geotherm. Res. In press.

Power, J., Wyss, M., Latchman, J.L., 1998. Spatial variations in the frequency-magnitude distribution of earthquakes at Soufrière Hills volcano, Montserrat, West Indies. Geophys. Res. Lett. 25:3653-3656.

Roman, D., Neuberg, J., Luckett, R., 2006. Assessing the likelihood of volcanic eruption through analysis of volcanotectonic earthquake fault-plane solutions. Earth and Planetary Lett. 248:229237.

Rowe, C., Thurber, C.H., White, R.A., 2004. Dome growth behaviour at Soufrière Hills Volcano, Montserrat, revealed by relocation of volcanic event swarms, 1995-1996. J. Volcanol. Geotherm. Res. 134:199-221.

Schlindwein, V., Wassermann, J., Scherbaum F., 1995. Spectral analysis of harmonic tremor signals at Mt. Semeru volcano, Indonesia. Geophys. Res. Lett. 22:1685-1688.

Sparks, R.S.J., Young, S., Barclay, J., Calder, E., Cole, P., Darroux, B., Davies, M., Druitt, T., Harford, C., Herd, R., James, M., Lejeune, A-M., Loughlin, S., Norton, G,. Skerritt, G., Stasiuk, M., Stevens, N., Toothill, J., Wadge, G., Watts, R., 1998. Magma production and growth of the lava 
dome of the Soufrière Hills Volcano, Montserrat, West Indies: November 1995 to December 1997. Geophys. Res. Lett. 25: 3421-3424.

Sparks, R.S.J., Murphy, M., Lejeune, A.M., Watts, R., Barclay, J., Young, S., 2000. Control on the emplacement of the andesite lava dome of the Soufriere Hills volcano, Montserrat by degassinginduced crystallization. Terra Nova 12:14-20

Voight, B., Sparks, R.S.J., Miller, A., Stewart, R.C., Hoblitt, R.P., Clarke, A., Ewert, J., Aspinall, W.P., Baptie, B., Calder, E.S., Cole, P., Druitt, T.H., Harford, C., Herd, R.A., Jackson, P., Lejeune, A-M., Lockhart, A.B., Loughlin, S.C., Luckett, R., Lynch, L.L, Norton, G.E., Robertson, R., Watson, I.M., Watts, R., Young S.R., 1999. Magma Flow Instability and Cyclic Activity at Soufrière Hills Volcano, Montserrat, British West Indies. Science, 283:1138-1142.

Young, S.R., Sparks, R.S.J., Aspinall, W.P., Lynch, L.L., Miller, A.D., Robertson, R., Shepherd, J.B., 1998. Overview of the eruption of Soufrière Hills Volcano, Montserrat, July 181995 to December 1997. Geophys Res Lett 25:3389-3392.

Zobin, V., 2003. Introduction to Volcanic Seismology. Elsevier, Amsterdam, 302 pp.

Figure 1: MVO seismic network from April 2006. The observatory is located near the station MBFL.

Figure 2: Daily seismic network event counts from October 2005 to May 2006. For comparison, counts for a similar time interval in 1996 and 1997 are also shown.

Figure 3: Frequency of the highest peak in the spectra of hybrid events recorded at MBGH. Those events with low signal-to-noise ratio have their highest peak between $0.2 \mathrm{~Hz}$ and $0.4 \mathrm{~Hz}$, at sea microseism frequencies. Otherwise the vast majority of events in 1997 have spectral peaks at near $1.2 \mathrm{~Hz}$ or $1.7 \mathrm{~Hz}$. By comparison, in $2005 / 2006$ hybrids did not generally have spectral peaks below $2 \mathrm{~Hz}$.

Figure 4: Hybrids from different years recorded at MBRY. Note the change in dominant frequency from between $1 \mathrm{~Hz}$ and $2 \mathrm{~Hz}$ in 1997 to between $3 \mathrm{~Hz}$ and $4 \mathrm{~Hz}$ in 2005 .

Figure 5: Location of the 120 best recorded hybrid earthquakes from 2005. Horizontal errors in these locations are of a few hundred metres but depth errors are between $1 \mathrm{~km}$ and $2 \mathrm{~km}$. The r.m.s. of the residuals are less than $0.1 \mathrm{~s}$ for all of these events.

Figure 6: Examples of long-period rockfall signals with the most obvious long-period energy before, during, and after the rockfall. These were all recorded on MBGH.

Figure 7: Comparison between two long-period earthquakes recorded at MBLG, one with dominant frequency near $1 \mathrm{~Hz}$ and one with dominant frequency near $4 \mathrm{~Hz}$.

Figure 8: Cumulative energy at station MBWH for events classified as rockfalls triggered during February 2006. February was chosen because unusually good dome visibility allows comparison with observations. 